\author{
흑운모 분말 급여 돈육의 이화학적 특성 \\ 진상근*김일석*.송영민*이성대*·하경희**.김회윤*남기윤*장애라*** \\ 진주산업대학교 국제축산개발학과*, 경상대학교 축산과학부**, 서울대학교 농생명공학부***
}

\title{
Effects of Dietary Biotite Powder on Physico-chemical Characteristics of Pork
}

\author{
S. K. Jin*, I. S. Kim*, Y. M. Song*, S. D. Lee*, K. H. Hah**, H. Y. Kim*, K. Y. Nam* \\ and A. R. Jang*** \\ Department of International Livestock Industry, Jinju National University*, \\ Division of Animal Science, College of Agriculture, Gyeongsang National University** \\ School of Agricultural Biotechnology, Seoul National University***
}

\begin{abstract}
This study was carried out to analyze the physico-chemical characteristics of the loin from pigs fed biotite. Control was fed diet for piglets and growing pigs, and treatments were fed diet supplemented $1.25 \%$ and $1.75 \%$ biotite to piglet diet and to growing pigs, respectively. Ratio of carcass grade A was shown as $27.8 \%$ and $50 \%$ in control group and treatment, respectively. And that of carcass grade A and B was appeared as $52.8 \%$ in control and $80 \%$ in treatment. The control group showed higher value of water and protein content than treatment. However, fat and ash content of treatment were higher than those of control. Treatment showed lower value than control in shear force and cooking loss, and was higher than control in $\mathrm{pH}$ value $(\mathrm{p}<0.05)$. $\mathrm{L}^{*}, \mathrm{a}^{*}$ and $\mathrm{b}^{*}$ value of control in meat color were lower than those of treatments. Treatments group was shown lower value than control group in textural gumminess and brittleness. In the sensory test of fresh meat, there was no significant difference between control and treatment group. However, intramuscular fat content and overall acceptability of control were more or less lower than its of treatment. In cooked meat, the meat color of control was lower than those of treatments. Control group was shown higher saturated fatty acid value than treatment group. However, the poly unsaturated fatty acid, essential fatty acid, and the ratio of unsaturated fatty acid/saturated fatty acid and essential fatty acid/saturated fatty acid were low.
\end{abstract}

(Key words : Biotite, Color, Texture, Sensory test, Fatty acid, Pork)

$$
\text { I. 서 론 }
$$

최근에 브랜드 돈육 생산차원에서 광물질에 대한 관심이 높아지면서 이들에 대한 연구들이 진행되어 황토 및 점토광물을 소에게 급여시
증체율 및 사료 이용성 등에 개선효과가 있고 배설물의 냄새를 줄이며 설사를 방지하는 효과 가 있다(Jacques 등, 1986)고 알려져 있다.

국내에서 생산되는 주요 점토광물로서 규산 염 광물질로는 zeolite, kaolin, bentonite 등이 있

Corresponding author: S. K. Jin, Department of International Livestock Industry, Jinju National University, 660-750, Jinju, Korea. Tel. : 82-55-751-3283, Fax:82-55-751-3514, E-mail : skjin@jinju. ac.kr 
으며, 이들은 규산염 $\left(\mathrm{SiO}_{2}\right)$ 을 $60 \%$ 내외 함유하 고 있다. Zeolite는 장내 과잉 수분을 흡수하여 연변을 방지하고 사료의 장내 통과시간을 지연 시켜 소화율을 향상시키는 효과가 있으며 (Harms와 Damron, 1973), Mumpton과 Fishman (1977)은 자연산 zeolite는 이온교환과 부착성을 가지고 있어서 사료의 영양소 이용율을 향상시 키고 장질환의 감소, 분 중의 수분 및 암모니 아의 감소를 나타내었다고 보고하였다. 이 외 점토광물질에도 illite, porphyry(맥반석) 등이 있 으며, 이러한 황토 및 점토광물질을 한우에 급 여 시 육질면에서 전단력 및 관능검사의 다즙 성, 연도 및 향미가 개선되었다(강 등, 2002a, 2002b)고 보고되었으며, 돼지에게 scoria 급여 시 도체등급의 상등급 출현율이 증가하고 육색 의 적색도 $\left(\mathrm{a}^{*}\right.$ 값)은 증가하였으며(양 등, $2000 \mathrm{a}$, 2000b), 규산염 광물질 급여가 돼지의 근육과 지방특성에 유리한 영향을 준다고 보고(Kovar 등, 1990; Pond 등, 1988)되었다. 한편 비육돈에 황토성분(illite) $1 \%$ 첨가 급여시 $\mathrm{pH}$, 보수력, 전단력, 육색 $\mathrm{L}^{*}$ 과 $\mathrm{a}^{*}$ 값 및 가열육의 풍미, 맛, 연도는 차이가 없었으며, 가열감량과 드립은 첨가구가 낮고 근내지방도 및 가열육의 다즙성 은 우수한 것으로 보고(김 등, 2000)되었다.

지금까지의 연구로는 흑운모 분말을 가축에 게 급여한 것은 없고 규산염 광물질을 급여한 시험이 있었으며, 돼지의 경우에서도 비육돈 위주로 제한되고 있어 본 연구에서는 흑운모 분말을 자돈 시부터 출하시까지 첨가 급여하여 도체등급 및 육질에 미치는 영향을 조사하고자
실시하였다.

\section{ㅍ. 재료 및 방법}

\section{1. 시험동물 및 사료}

시험동물은 삼원교잡종 $(\mathrm{LY} \times \mathrm{D})$ 을 각 처리구 별로 20 두씩 배치하여 같은 사육환경에서 $\mathrm{P}$ 회 사의 사료(Table 1)를 무제한 급여하여 사육하 였으며, 처리구에는 56 일령부터 110 일령까지는 자돈용 사료에 흑운모 분말을 $1.25 \%$ 첨가하여 사육하였고, 111 일령부터 155 일령 출하시까지 는 육성용 사료에 흑운모 분말을 $1.75 \%$ 첨가하 여 사육하였다. 첨가한 흑운모 분말의 화학적 조성은 Table 2 와 같다.

Table 1. Chemical composition of the experiment diets

\begin{tabular}{lcc}
\hline Compositions & Starter & Grower \\
\hline \hline Crude protein(\%) & 17.5 & 15.0 \\
Crude fat(\%) & 5.5 & 4.0 \\
Crude fiber(\%) & 5.0 & 5.0 \\
Crude ash(\%) & 7.0 & 8.0 \\
Ca(\%) & 0.55 & 0.55 \\
P(\%) & 0.50 & 0.45 \\
Lysine(\%) & 1.20 & 0.5 \\
\hline DE(Mcal/kg) & 3.45 & 3.35 \\
DCP(\%) & 14.5 & 12.5 \\
\hline
\end{tabular}

Table 2. Chemical composition of biotite powder

\begin{tabular}{cccccc}
\hline $\mathrm{SiO}_{2}$ & $\mathrm{AI}_{2} \mathrm{O}_{3}$ & $\mathrm{~K}_{2} \mathrm{O}$ & $\mathrm{FeO}_{3}$ & $\mathrm{Na}_{2} \mathrm{O}$ & $\mathrm{CaO}$ \\
\hline \hline 68.26 & 14.83 & 6.50 & 4.05 & 2.82 & 1.88 \\
\hline $\mathrm{MgO}$ & $\mathrm{TiO}_{2}$ & $\mathrm{P}_{2} \mathrm{O}_{5}$ & $\mathrm{MnO}$ & Igloss & \\
\hline 0.07 & 0.44 & 0.32 & 0.03 & 0.73 & \\
\hline
\end{tabular}


2. 분석시료 및 분석방법

육질분석용 시료는 각 처리구별로 도축 후 24 시간 냉각된 도체 중 $\mathrm{A}, \mathrm{B}$ 등급을 받은 5 두 를 무작위로 추출하여 채취한 등심부위 근육을 시험에 공시하였다.

\section{(1) 일반성분}

시료의 일반성분 정량은 $\mathrm{AOAC}(1995)$ 방법에 준하여 수분 함량은 oven 건조법, 조단백질 함 량은 Micro Kjeldahl법, 조지방 함량은 Soxhlet 법, 조회분 함량은 건식회화법을 이용하였고, 시험용 시료는 돼지고기 등심부위에서 피하지 방, 근간지방 및 근막을 완전히 제거한 적육 부분을 이용하였다.

(2) 가열감량

가열감량은 일정한 규격으로 절단한 시료의 무게를 측정한 후 oven에서 중심온도가 $70^{\circ} \mathrm{C}$ 에 도달할 때까지 가열하였고, 가열된 시료는 상 온에서 냉각한 후에 시료의 무게를 측정하였으 며, 감량된 무게를 백분율(\%)로 환산하여 나타 내었다.

(3) $\mathrm{pH}$

육은 근막, 지방 등을 제거한 후 세절하여 $10 \mathrm{~g}$ 을 증류수 $90 \mathrm{ml}$ 와 함께 homogenizer(IKA,
T25 Basic Malaysia)로 균질하여 pH-meter(Orion $230 \mathrm{~A}, \mathrm{USA})$ 로 측정하였다.

(4) 조직감

조직감은 Rheometer(EZtest, shimadze, Japan) 를 이용하여 신선육은 shearing cutting test로 가열육은 masticaion test로 파쇄성(brittleness), 경도(hardness), 응집성(cohesiveness), 탄력성(springiness), 점착성(gumminess), 부착성(adhesiveness)을 조사하였으며, 이때의 분석조건은 chart speed $120 / \mathrm{mm} / \mathrm{min}$, maximum load $10 \mathrm{~kg}$, 측정속 도 $20 \mathrm{~mm}$, 시료높이 $20 \mathrm{~mm}$, adapter No. 4 로 측 정하였다.

(5) 육색

표면 육색은 chromameter(Minolta Co. CR 301 , Japan)를 이용하여 동일한 방법으로 5 회 반복하여 측정하여 명도(lightness)를 나타내는 $\mathrm{L}^{*}$ 값, 적색도(redness)를 나타내는 $\mathrm{a}^{*}$ 값과 황색 도(yellowness)를 나타내는 $\mathrm{b}$ *값을 측정하였다. 이때 표준색은 $\mathrm{L}^{*}$ 값이 $89.2, \mathrm{a}^{*}$ 값이 $0.921, \mathrm{~b}^{*}$ 값이 0.783 인 표준색판을 사용하여 표준화한 다음 측정하였다.

(6) 지방산

지질 추출은 Folch(1957)의 방법으로 시료 $50 \mathrm{~g}$ 에 Folch 용액 $\left(\mathrm{CHCl}_{3}: \mathrm{CH}_{3} \mathrm{OH}=2: 1\right)$ 을 넣

Table 3. GLC conditions for analysis of fatty acid

\begin{tabular}{ll}
\hline \multicolumn{1}{c}{ Item } & \multicolumn{1}{c}{ Conditions } \\
\hline \hline Instrument & Hewlett Packard 6890 Gas chromatography \\
Column & HP-5 5MS fused silica capillary column \\
& $30 \mathrm{~m} \times 0.25$ i.d \\
Temperature program & $2^{\circ} \mathrm{C} / \mathrm{min}$ \\
Detector & Flame Ionization Detector(FID) \\
Split ratio & $90: 1$ \\
\hline
\end{tabular}


고 균질화하여 지질을 추출한 후 가수분해하고 methylation 시킨 후 GLC를 이용하여 분석하였 으며, GLC 조건은 Table 4와 같다.

(7) 관능검사

각 시료에 대하여 관능검사 요원 10 명을 선 발하여 9점 척도법으로 관능검사를 실시하였 다. 신선육에서는 육색, 향, 육즙참출, 근내지방 도, 전체적 기호도의 항목으로 관능검사를 실 시하였고 가열육에서는 육색, 풍미, 맛, 다즙성, 조직감, 전체적 기호도의 항목으로 관능검사를 실시하였다.

\section{3. 통계처리}

이상의 실험에서 얻어진 결과는 $\mathrm{SAS}(1999)$ 의 GLM(General Linear Model) 방법으로 분석하였 고 처리 평균간의 비교를 위해 Duncan의 Multiple Range Test가 이용되었다.

\section{III. 결과 및 고찰}

\section{1. 등급 출현율}

흑운모 분말을 첨가 급여한 돼지의 등급 출 현율은 Table 4에 나타내었다. 155일령에 출하 하였을 때, 생체중은 대조구 $107.4 \mathrm{~kg}$ 에 비하여 처리구가 $114.8 \mathrm{~kg}$ 으로 더 높게 나타났다. 등급
출현율에서 A 등급 출현율은 대조구가 $27.8 \%$ 인 반면, 처리구는 $50 \%$ 를 나타내었으며, $\mathrm{A}, \mathrm{B}$ 등급 출현율은 대조구가 $52.8 \%$, 처리구가 $80 \%$ 를 나타내어 흑운모 분말 급여가 상위 등급을 $27 \%$ 나 높게 받는 것으로 나타났다. 이는 돼지 에게 Scoria 급여시 도체등급의 상등급 출현율 이 증가한다는 양 등 $(2000 \mathrm{a}, 2000 \mathrm{~b})$ 의 보고와 일치하는 결과를 나타내었다.

\section{2. 육의 일반성분}

흑운모 분말 첨가 급여가 돈육의 일반성분에 미치는 영향은 Table 5에 나타내었다. 처리구의 수분과 조단백질은 74.1과 18.4로 대조구의 75.2와 19.0에 비하여 낮게 나타났으나 $(\mathrm{P}<0.05)$, 조지방과 조회분은 처리구가 3.0 과 1.5 로 대조 구의 2.2와 1.1 에 비하여 높게 나타나 $(\mathrm{P}<0.05)$ 근육내 지방 침착에 기여하는 결과를 나타내었 다. 이는 비육돈에 $1 \%$ 의 황토성분(Illite)을 첨 가 급여하였을 때, 근내지방도가 우수하였다는 김 등(2000)의 결과와 일치하였다.

\section{3. 육의 이화학적 특성}

흑운모 분말 첨가 급여가 돈육의 $\mathrm{pH}$, 전단 력, 가열감량에 미치는 영향은 Table 6에 나타 내었다.

육의 물리적 성질 중 $\mathrm{pH}$ 는 식육의 품질을 좌우하는데, $\mathrm{pH}$ 의 고저에 따라 신선도, 보수성,

Table 4. Effects of dietary biotite powder on live weight and final carcass grade

\begin{tabular}{lccccc}
\hline & Live wt. & A & B & C & D \\
\cline { 3 - 6 } Treatments & $(\mathrm{kg})$ & & & $(\%)$ & \\
\hline \hline Control & 107.4 & 27.8 & 25 & 27.8 & 19.4 \\
Treatment & 114.8 & 50 & 30 & 10 & 10 \\
\hline
\end{tabular}

1) Control : Control, Treatment : Biotite powder addition. 
Table 5. Effects of dietary biotite powder on crude composition of loin eye section

\begin{tabular}{lcccc}
\hline Treatments $^{1)}$ & Moisture & Crude protein & Crude fat & Crude ash \\
\hline \hline Control & $75.2 \pm 0.9^{\mathrm{A}}$ & $19.0 \pm 0.5^{\mathrm{A}}$ & $2.2 \pm 0.3^{\mathrm{B}}$ & $1.1 \pm 0.07^{\mathrm{B}}$ \\
Treatment & $74.1 \pm 0.9^{\mathrm{B}}$ & $18.4 \pm 0.5^{\mathrm{B}}$ & $3.0 \pm 0.3^{\mathrm{A}}$ & $1.5 \pm 0.02^{\mathrm{A}}$ \\
\hline
\end{tabular}

A,B : Means with different superscript in the same column significantly differ $\mathrm{p}<0.05$.

1) Treatments are the same as described in Table 4.

Table 6. Effects of dietary biotite powder on pH, shear force and cooking loss of loin eye section

\begin{tabular}{lccc}
\hline Treatments $^{1)}$ & $\mathrm{pH}$ & Shear force $\left(\mathrm{kg} / \mathrm{cm}^{2}\right)$ & Cooking loss $(\%)$ \\
\hline \hline Control & $5.4 \pm 0.1^{\mathrm{B}}$ & $115,890 \pm 4,410^{\mathrm{A}}$ & $36.0 \pm 1.2^{\mathrm{A}}$ \\
Treatment & $5.6 \pm 0.1^{\mathrm{A}}$ & $105,453 \pm 5,249^{\mathrm{B}}$ & $32.4 \pm 1.9^{\mathrm{B}}$ \\
\hline
\end{tabular}

$\mathrm{A}, \mathrm{B}$ : Means with different superscript in the same column significantly differ $\mathrm{p}<0.05$.

1) Treatments are the same as described in Table 4.

연도, 결착력, 육색, 조직감 등이 크게 영향을 낮게 $(\mathrm{P}<0.05)$ 나타나 $\mathrm{pH}$ 가 전단력과 가열감량 받으며, 저장성에 있어서도 중대한 요인으로 에 큰 영향을 미치는 것으로 나타났으며 최종 작용하기 때문에 육 품질 연구의 기본이 된다 $\mathrm{pH}$ 가 높은 경우 보수력을 증진시킨다는 보고 고 알려져 있다. $\mathrm{pH}$ 는 처리구가 대조구보다 높 (Lanier 등, 1977)와 같은 경향을 나타내었다.

게 나타났으며 $(\mathrm{P}<0.05)$, 가열감량은 대조구에 비하여 처리구가 낮게 나타났는데 $(\mathrm{P}<0.05)$, 이 는 사후 육의 $\mathrm{pH}$ 가 높으면 보수력 또한 높아 가열감량이 감소하며 이러한 감량은 육의 부위 와 결체조직 등에 의해서 영향을 받는다고 보 고한(Honikel 등, 1986) 것과 같은 경향을 나타 내었다. 전단력은 대조구에 비하여 처리구가

4. 육 색

흑운모 분말 첨가 급여가 돈육의 육색에 미 치는 영향은 Table 7에 나타내었다. 신선육의 육색은 매장에서 최초로 소비자가 구입을 결정 하게 하는 유일한 품질특성이다. 육색소(myo-

Table 7. Effects of dietary biotite powder on CIE value of loin eye section

\begin{tabular}{lccc}
\hline & \multicolumn{3}{c}{ CIE value } \\
\cline { 2 - 4 } Treatments $^{1)}$ & $\mathrm{L}$ & $\mathrm{a}$ & $\mathrm{b}$ \\
\hline \hline Control & $50.8 \pm 2.5$ & $2.4 \pm 0.9$ & $9.7 \pm 0.8$ \\
Treatment & $51.7 \pm 2.8$ & $3.1 \pm 0.8$ & $10.0 \pm 0.9$ \\
\hline
\end{tabular}

1) Treatments are the same as described in Table 4. 
globin)와 혈색소(hemoglobin)가 관련된 색택의 변화는 신선육 구매시 구입 척도로써 가장 중 요하게 작용하게 되는데, 신선육 표면에 있어 서 갈색 색소가 총 색소의 $30 \sim 40 \%$ 에 도달하 게 되면 소비자들은 구매를 기피한다(Greene 등, 1971)고 하였다.

육색은 주로 명도(lightness)와 적색도(redness) 를 주로 관찰하며 적색도가 높을수록 좋은 품 질로 평가받고 있다. 고기의 명도를 나타내는 $\mathrm{L}^{*}$ 값, 적색도를 나타내는 $\mathrm{a}^{*}$ 값과 황색도를 나 타내는 $\mathrm{b}^{*}$ 값 모두 처리구가 대조구에 비해 높 게 나타나 밝은 선홍색을 띄었으나 유의적인 차이는 없었다. 이는 비육돈에 $1 \%$ Illite 첨가 급여시 육색 $\mathrm{L}^{*}$ 과 $\mathrm{a}^{*}$ 값은 유의적인 차이를 보 이지 않았다는 보고(김 등, 2000)와 일치하는 결과였다.

\section{5. 조직감}

흑운모 분말 첨가 급여가 돈육의 조직감에 미치는 영향은 Table 8에 나타내었다. 육류의 화학적 조성도 육의 구조에 영향을 미치며, 물 리적 성질을 결정하는데 관여한다. 이러한 복 잡한 요인에 의해 육류의 조직감이 결정되고, 관능적 특성도 아울러 결정된다. 육의 조직감 측정은 육질을 평가하는데 가장 중요한 방법중 의 하나이며, 육류의 조직은 소비자들이 육의 맛을 평가하는데 중요한 기준이 된다. 반고체 식품을 삼킬 수 있는 정도로 씹는데 필요한 에
너지인 점착성과 부서지는 성질을 나타내는 파 쇄성은 대조구에 비하여 처리구가 낮게 나타났 으며 $(\mathrm{P}<0.05)$, 식품의 표면과 접촉하는 다른 물 질(이, 혀, 입천장)의 표면간의 인력을 초과하 는데 필요한 힘을 나타내는 부착성, 물질을 변 형시킬 때 필요한 힘을 나타내는 경도, 식품의 형태를 구성하는 내부적 결합에 필요한 힘을 나타내는 응집성과 물체에 외부로부터 힘을 가 한 후 생긴 변형이 힘을 제거시 원상 복귀하는 성질을 나타내는 탄력성 모두 처리구가 대조구 에 비해 낮아 처리구가 대조구에 비하여 조직 감이 개선되는 것으로 나타났으나 유의적인 차 이는 없었다.

\section{6. 신선육 관능검사}

흑운모 분말 첨가 급여가 신선 돈육의 관능 평가에 미치는 결과를 Fig. 1에 나타내었다. 생 육에서의 육색과 불쾌취는 최종 소비자가 구입 할 때에 매우 중요하게 작용하는 관능적인 요 인으로 육색, 향, 상강도 및 기호성은 점수가 높을수록 좋고, 육즙 참출은 점수가 낮을수록 좋은 고기이다. 선선육의 관능검사에서 육색은 대조구에 비하여 처리구가 다소 낮게 나타났 고, 육즙 참출은 대조구에 비하여 처리구가 적 게 나타났는데 육색과 육즙 참출 모두 유의적 인 차이는 없었다 $(\mathrm{p}>0.05)$. 또한 향과 근내지방 점수에서는 흑운모 급여 돈육이 높게 나타나 전체적인 기호도에서 대조구에 비하여 처리구

Table 8. Effects of dietary biotite powder on texture of loin eye section

\begin{tabular}{lcccccc}
\hline Treatments $^{1)}$ & Adhesiveness & Hardness & Cohesiveness & Springiness & Gumminess & Brittleness \\
\hline \hline Control & $347 \pm 28$ & $31,378 \pm 1,369$ & $40 \pm 3$ & $87 \pm 6$ & $467 \pm 29^{\mathrm{A}}$ & $416 \pm 22^{\mathrm{A}}$ \\
Treatment & $332 \pm 47$ & $26,955 \pm 1,415$ & $38 \pm 2$ & $84 \pm 4$ & $409 \pm 17^{\mathrm{B}}$ & $339 \pm 32^{\mathrm{B}}$ \\
\hline
\end{tabular}

\footnotetext{
$\mathrm{A}, \mathrm{B}$ : Means with different superscript in the same column significantly differ $\mathrm{p}<0.05$.

1) Treatments are the same as described in Table 4.
} 
가 좋은 점수를 나타내었지만 유의적인 차이는 나타나지 않았다 $(\mathrm{p}>0.05)$.

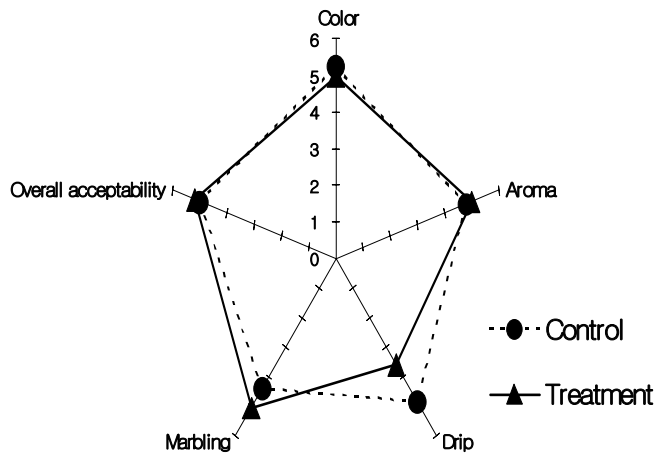

Fig. 1. Effects of dietary biotite powder on sensory test of fresh loin eye section.

Control : Control, Treatment : Biotite powder addition

\section{7. 가열육 관능검사}

흑운모 분말 첨가 급여가 가열 돈육의 관능 평가에 미치는 결과는 Fig. 2에 나타내었다. Crocker(1948)는 원료육은 거의 냄새(order)를 가지지 않고 단지 혈액 같은 맛만 제공하지만 조리시에 고기의 풍미를 생성한다고 하였다. 가열시에 발생하는 주요한 반응은 당의 분해, 단백질과 아미노산의 열 분해 및 지질의 분해 를 포함한다. 식육의 기호성은 가열육을 입 속 에서 씹어 넘기는 과정에 혀의 감각으로 느껴 지는 맛, 후각으로 느껴지는 향, 그리고 조직감 등을 포함하여 판단하게 된다. 이들 중 어느 것이 기호성에 크게 관여하는지는 식육의 종류 에 따라 다르며 우육의 경우 맛보다 향과 조직 감이 크게 관여한다고 알려져 있다(沖, 1992).

가열육의 관능검사에서 육색은 처리구가 대 조구에 비해 높게 나타났고 $(\mathrm{P}<0.05)$, 향, 맛, 조 직감, 다즙성 및 전체적인 기호도는 처리구가 높은 경향을 나타내었으나 유의적인 차이는 없 었다. 이는 비육돈에 $1 \%$ Illite 첨가 급여시 가
열육의 풍미, 맛, 연도는 차이가 없었으며, 다 즙성은 처리구가 대보구보다 우수하였다는 보 고(김 등, 2000)와 비슷한 경향을 보였다.

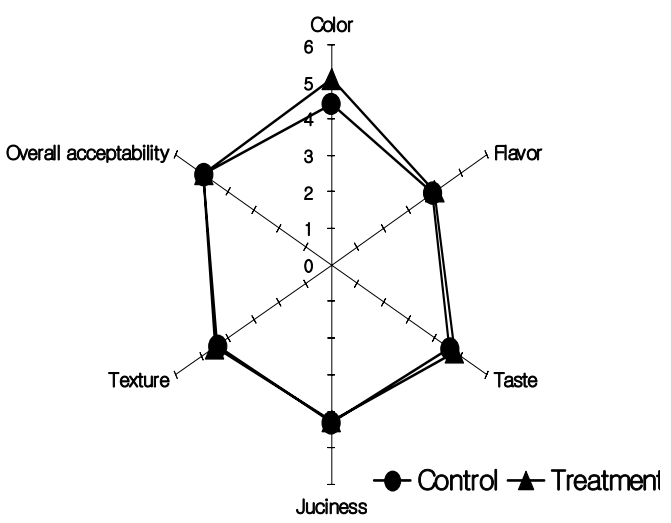

Fig. 2. Effects of dietary biotite powder on sensory test of cooked loin eye section.

Control : Control, Treatment : Biotite powder addition

8. 지방산

흑운모 분말을 첨가 급여한 돈육의 지방산 조성은 Fig. 3에 나타내었다. 지방산은 지질을 가수분해할 때 얻어지는 유기산으로서 글리세 롤과 에스터 결합에 의해 지질을 형성한다. 이 러한 지방산은 지질의 특성을 결정짓는 주요 요소이며 그 조성에 따라 체내에서의 지질의 역할이 서로 달라지게 된다. 따라서 식육의 품 질특성이나 저장성에 미치는 영향 중에서 지질 의 함량 및 지방산 조성은 육의 근내지방도와 도체의 등급에 영향을 줄 뿐만 아니라, 고기의 맛과 풍미 등 기호도에도 영향을 준다(Dryden 과 Marcgello, 1960; Hornstein 등, 1967). 하지 만 단위동물의 경우 근육 내 지방산의 조성은 식이를 통해서 바꿀 수 있다고 보고되었는데 (Miller 등, 1990), 지방산 조성은 myristic $\operatorname{acid}(\mathrm{C} 14: 0)$, palmitic $\operatorname{acid}(\mathrm{C} 16: 0)$, stearic acid (C18:0)와 같은 포화 지방산이나 palmitoleic 
$\operatorname{acid}(\mathrm{C} 16: 1)$, oleic $\operatorname{acid}(\mathrm{C} 18: 1)$ 와 같은 단일 불포 화지방산은 대조구에 비하여 처리구가 낮게 나 타났으나, linoleic $\operatorname{acid}(\mathrm{C} 18: 2)$ 와 arachidonic $\operatorname{acid}(\mathrm{C} 20: 4)$ 와 같은 다가 불포화지방산은 처리 구가 대조구에 비해 높게 나타났다 $(\mathrm{P}<0.05)$.

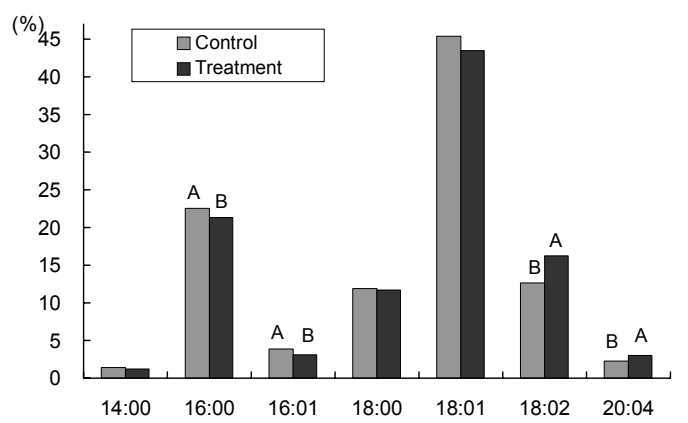

Fig. 3. Effects of dietary biotite powder on fatty acid composition of loin eye section.

흑운모 분말을 첨가 급여한 돈육의 지방산 중 포화지방산(SFA), 불포화지방산(UFA), 필수 지방산(EFA), UFA/SFA, EFA/SFA 비율을 Fig. 4에 나타내었다. SFA는 대조구에 비하여 처리 구가 낮게 나타났으며 $(\mathrm{P}<0.05), \mathrm{UFA}$ 와 $\mathrm{EFA}$ 는 대조구에 비하여 처리구가 높게 나타났다 $(\mathrm{P}<$ 0.05). 또한 UFA/SFA, EFA/SFA 비율에서도 대 조구에 비해 처리구가 높게 나타났다 $(\mathrm{P}<0.05)$. 이는 돼지에게 규산염 광물질 급여가 근육과 지방특성에 유리한 영향을 준다는 보고(Kovar 등, 1990; Pond 등, 1988)와 일치하였다.

한국보건사회연구원(1991)에서는 포화지방산 의 섭취가 많은 사람들에게 동맹경화증의 발생 이 높다는 것을 경고하면서 섭취하는 지방의 포화지방산 : 불포화지방산의 비율이 $1: 1 \sim 1: 1.2$ 가 되도록 할 것을 권장하고 있으며, 또한 불 포화지방산이 혈액 고밀도 지단백 콜레스테롤 (HDL-콜레스테롤) 함량을 변화시키지 않으면 서 혈액 유해 콜레스테롤 함량을 낮출 수 있음
을 보고하였다(Grundy, 1987). 이러한 흑운모 분말 급여를 통해 지방산 조성을 개선함으로써 국민 건강에 기여할 수 있고, 브랜드 돈육으로 서의 잠재적인 수요를 자극하여 소비량을 증가 시키는데 일익을 담당할 수 있으리라 사료된 다.

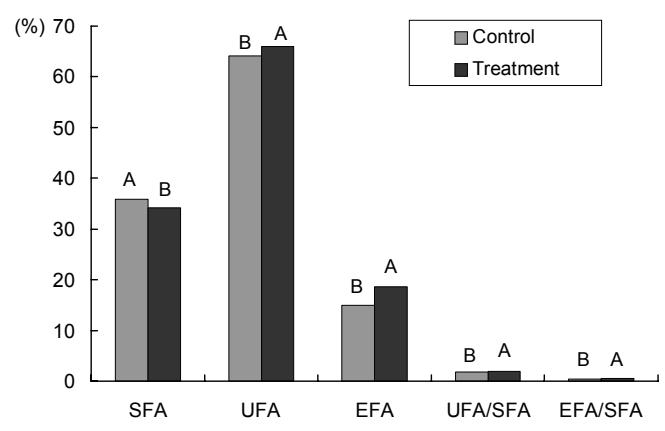

Fig. 4. Effects of dietary biotite powder on SFA, UFA, EFA, UFA/SFA and $E F A / S F A^{1)}$ of loin eye section.

1) SFA(Saturated fatty acid), UFA(Unsaturated fatty acid), EFA(Essential fatty acid).

\section{IV. 요 약}

돼지 $(\mathrm{LY} \times \mathrm{D})$ 의 자돈용 및 육성용 기본사료 를 급여한 대조구와 자돈용 사료에 흑운모 분 말 $1.25 \%$, 육성용 사료에 $1.75 \%$ 를 첨가한 처리 구 등심육의 이화학적 특성을 분석한 결과는 다음과 같다.

$\mathrm{A}$ 등급 출현율은 대조구가 $27.8 \%$ 인 반면, 처 리구는 $50 \%$ 를 나타내었으며, $\mathrm{A}, \mathrm{B}$ 등급 출현 율은 대조구가 $52.8 \%$, 처리구가 $80 \%$ 를 나타내 었다. 수분과 단백질은 대조구가 처리구보다 높게 나타났으나 $(\mathrm{P}<0.05)$, 지방과 회분은 처리 구가 높게 나타났다 $(\mathrm{P}<0.05)$. 전단력과 가열감 량은 처리구가 대조구보다 낮게 나타난 반면, $\mathrm{pH}$ 는 높게 나타났다 $(\mathrm{p}<0.05)$. 육색의 $\mathrm{L} *$ 값, $\mathrm{a}^{*}$ 값 및 $\mathrm{b}$ *값 모두 처리구가 대조구에 비해 높은 
경향을 나타내었다. 조직감의 검성과 파쇄성은 처리구가 대조구에 비해 낮게 나타났다 $(\mathrm{P}<$ 0.05). 선선육의 관능검사에서 대조구와 처리구 간에 항목별로 유의적인 차이는 없었으나 근내 지방도 및 전체적인 기호도에서 처리구가 대조 구보다 다소 높게 나타났으며, 가열육의 관능 검사에서 육색은 처리구가 대조구에 비해 높게 나타났다. 지방산 조성 중 포화지방산은 처리 구에 비하여 대조구가 높게 나타난 반면 다가 불포화지방산, 필수지방산, 불포화지방산/포화 지방산 및 필수지방산/포화지방산의 비율은 낮 게 나타났다.

\section{$\mathrm{V}$. 인 용 문 헌}

1. AOAC. 1995. Official Method of Analysis 15th ed., Association of Official Analytical Chemists. Washington, DC.

2. Crocker, E. C. 1948. The flavor of meat. Food Res. 13:179.

3. Dryden, F. D. and Marcgello, J. A. 1960. Influernce of total lipid and fatty acid composition upon the palatability of three bovine muscle. J. Animal Sci. 31:36

4. Folch, J., Lees, M. and Sloan-Stanley, G. N. 1957. A simple method for the isolation and purification and purification of total lipides from animal tissues. J. Biol. Chem. 226:497.

5. Greene, B. E., Hsin, I. and Zipser, M. W. 1971. Retardation of oxidative color changes in raw ground beef. J. Food Sci. 36:940.

6. Grundy, S. M. 1987. Monounsaturated fatty acids, plasma cholesterol and coronary heart disease. Am, J. Clin. Nutr. 45:1168.

7. Harms, R. H. and Darmron, R. H. 1973. The influence of various dietary follers on the utilization of energy by poultry. Poult. Sci. 52: 2034.

8. Honikel, K. O., Kim, C. J. and Hamm, R. 1986. Sarcommere shortening of prerigor muscles and its influence on drip loss. Meat Sci. 16:267.

9. Hornstein, I., Growe, P. F. and Heimerg, M. J. 1967. Fatty acid composition of meat tissue lipid. J. Food Sci. 26:581.

10. Jacqes, K. A., Axe, D. E., Haris, T. R., Harmon, D. L., Bolson, K. K. and Johnson, D. E. 1986. Effect of sodium bicarbonate and sodium bentonite on digestion solid and liquid flow and ruminal fermentation characteristics of forage sorghum silage-based diets fed to steers. J. Anim. Sci. 70:1391.

11. Kovar, S. J., Ingram, D. R., Hagedom, T. K., Achee, V. N., Barnes, D. G. and Laurent, S. M. 1990. Broiler performance as influenced by sodium zeolite-A. Poultry Sci. 69(Suppl. 1):174.

12. Lanier, T. C., Carpenter, J. A. and Toledo, R. T. 1977. Effects of cold storage environment on color of exposed lean beef surfaces. J. Food Sci. 42:860.

13. Miller, M. F., Shackelford, S. D., Hayden, K. D. and Reagan, J. O. 1990 Determination of the alteration in fatty acid profiles, sensory characteristics and carcass traits of swine fed dldvated levels of monounsaturated fats in the diet. J. Anim. Sci. 68:1624.

14. Mumpton, F. A. and Fishman, P. H. 1977. The application of natural zeolites in animal science. J. Anim. Sci. 45:1188.

15. Pond, W. G., Yen, J. T. and Varel, V. H. 1988. Response of growing swine to dietary copper and clinoptilolite supplementation. Nutr. Rep. Int. 37:795.

16. SAS. 1999. SAS user's guide. Statistical analysis system institute, Inc., Cary, NC.

17. 沖谷明, 森壽一郎, 松石昌典. 1992. 牛肉の含氣 熱成による香りの向上. 日畜會報, 63:189.

18. 강수원, 김준식, 조원모, 안병석, 기광석, 손용석. 2002a. 육성비육 거세한우에 대한 점토광물 급여 가 성장 및 도체특성에 미치는 효과. 한국동물자 원과학회지. 44(3):327.

19. 강수원, 김준식, 조원모, 정하연, 기광석, 최성복. 2002b. 육성비육 거세한우에 대한 황토 급여가 
성장 및 도체특성에 미치는 효과. 한국동물자원 과학회지. 44(3):315.

20. 김천제, 이의수, 송민석, 조진국. 2000. 황토성분 (Illite) 첨가 급여가 비육돈의 육질에 미치는 영 향. 한국축산삭품학회지. 20(2):152.

21. 양창법, 김진동, 이지훈, 조원탁, 한인규. $2000 \mathrm{a}$. 돼지사료중 제주 화산암 분말(Scoria)과 Zeolite가
산육능력에 미치는 영향. 42(4):477.

22. 양창법, 김진동, 조원탁, 한인규. $2000 \mathrm{~b}$. 사료중 제주 화산암 분말(Scoria)이 돼지의 산육능력에 미치는 영향. 한국동물자원과학회지. 42(4):467.

23. 한국보건사회연구원. 1991. 한국인의 영양권장량 (제 5차개정). P.15.

(접수일자 : 2003. 3. 19 / 채택일자 : 2003. 4. 22) 